\title{
Analysis of The Influence Rupiah Exchange Rate on Economic Growth in Indonesia
}

\author{
Bima Hardi ${ }^{1 *}$, Indra Maipita ${ }^{1}$, Fitrawaty ${ }^{1}$ \\ ${ }^{1}$ Universitas Negeri Medan \\ "Corresponding author. Email: bimahardi0801@gmail.com
}

\begin{abstract}
Economic growth as a benchmark of achievement of economic activity in Indonesia in obtaining additional income for its people from one period to the next. As a result of the Covid-19 pandemic, Indonesia's economic growth and even the world has experienced a setback. Therefore, the Indonesian state made various efforts to increase economic growth. Currency stability is the key to accelerating the pace of economic growth in any country. The purpose of this study is to analyze the short- and long-term effects of the rupee exchange rate on Indonesia's economic growth. The data used in this study are secondary time series data for Bank Indonesia Q1 2011 - Q2 2021. The analysis method used in this study is ECM (Error Correction Model). The results showed that in the short term, the rupiah exchange rate had a significant positive impact on economic growth and the Covid 19 dummy had a significant negative impact on economic growth. In the long run, the rupiah exchange rate and the Covid19 dummy will not have a significant impact on Indonesia's economic growth.
\end{abstract}

Keywords: Rupiah Exchange Rate, Dummy Covid-19, Economic Growth.

\section{INTRODUCTION}

A COVID 19 pandemic in Wuhan, China in late 2019 could warn international financial markets, slow down the global economy, plunge various countries into a serious recession and spread a widespread economic crisis. [2]. Indonesia's province faces financial difficulties and other obstacles as Indonesia is one of the countries affected by the Covid-19 pandemic. Indonesia continues to seek to meet the economic needs of the country's development process in order to achieve national welfare to catch up with the recession caused by the pandemic Covid-19.

Economic growth as one of the important indicators to measure success in the economic development of a country is the full attention of the government in advancing the country's economy. In the current economic climate, growth remains a government priority, and economic growth literature is directed at the state's political, legal, economic and social influences on prosperity and long-term growth increase [8].

Economic growth as a measure of achievement of economic activity in Indonesia in obtaining additional income for its people from one period to the next. High economic growth in a country can encourage faster development activities in a country. The following is data on Indonesia's economic growth.

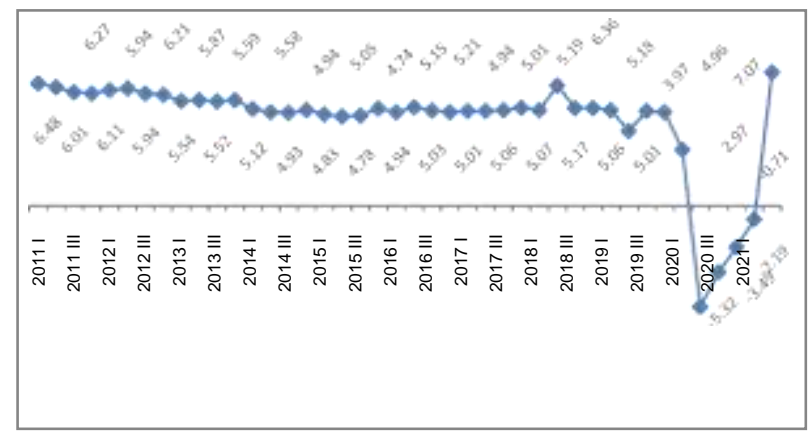

Figure 1 Indonesia's Economic Growth in 2011 Q1-2021 Q2 (in \%). Source: Bank Indonesia 2021

From the graph above, it shows that the movement of economic growth fluctuated from the first quarter of 2011 to the fourth quarter of 2020. At the beginning of the observation in the first quarter of 2011 Indonesia's economic growth was $6.45 \%$, the Indonesian economy slowed down until 
the third quarter of 2014 only grew by $2.96 \%$. and rose again in the 4th quarter of 2014 which grew by $5.02 \%$. At the end of 2019 Indonesia was hit by the Covid-19 virus disaster which caused the economy to slow down and only grow $2.97 \%$ in the 1 st quarter of 2020 and the Indonesian economy experienced a slump because of its growth of $5.32 \%$ in the 2nd quarter of 2020 and increased in 2021 the 2nd quarter of growth Indonesia's economy is at $7.07 \%$. Entering the first quarter, COVID-19 began to suppress Indonesia's economic growth. The national economy grew by $2.97 \%$ (yoy) in the first quarter of 2020, slower than the previous quarter, due to declining economic growth performance in almost all regions, except for South Kalimantan and Papua. In most areas, net-export performance held back a deeper growth slowdown. Exports of main regional commodities are still growing, especially in Sumatra, Java, Kalimantan and Sulampua. Meanwhile, the export performance of Balinusra's services contracted quite deeply. With the impact of COVID-19, Indonesia's economic growth in 2020 is estimated to slow down, which occurs in almost all regions, except Sulampua, which is supported by mining products [1].

As a result of Indonesia's slowing economic growth and not growing in 2020 due to the Covid19 virus, the government and monetary authorities have made various policies to maintain economic stability with various efforts. In fact, the banking sector is very important for economic development and growth. Monetary policy is one of the government's efforts to control macroeconomic conditions so that they can run as expected. Monetary policy is a policy undertaken to achieve internal balance (price stability, equitable development and economic growth) and external balance (balance of payments balance).

The monetary authority in facing the economic crisis is expected to maintain the stability of the Rupiah Exchange Rate. In maintaining the stability of the rupiah exchange rate, the monetary policy implemented by Bank Indonesia predicts that the rupiah will be stable and tend to strengthen at Rp. 15,000 per USD. The following is a graph of the rupiah exchange rate.

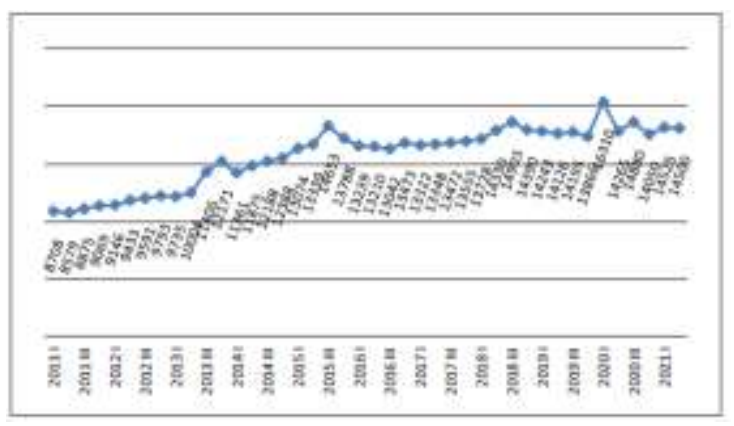

Figure 2 Development of Rupiah Exchange Rate Against USD in 2011 Q1 - 2021 Q2

Source: Bank Indonesia 2021

From the picture above, the rupiah continues to depreciate against the USD from the initial observation in 2011 quarter 1 to quarter 2 in 2021. In the first quarter of 2011 the rupiah exchange rate of 8708 per USD depreciated until the 4th quarter of 2013 worth 12171 per USD, appreciated in the first quarter in 2014 valued at 11361 per USD. In the 3rd quarter of 2015 it depreciated again at 14653 per USD and continued to depreciate until the 1st quarter of 2020 worth 16310. In this case, Bank Indonesia has a target to strengthen the value of the rupiah at a price of IDR $15,000 / \mathrm{USD}$, this was achieved in the 2 nd quarter of 2020 worth IDR $14,265 /$ USD until the 2nd quarter of 2021 worth IDR $14,500 /$ USD.

The rupiah exchange rate strengthened in accordance with dynamic market mechanisms, so that it could not be separated from the role of market players and exporters who took part in maintains the stability of the rupiah exchange rate. This enhancement reduces the need for Indonesia Bank to stabilize the rupiah exchange rate. The rise in the rupiah rate was affected by several factors. That is, the rupiah rate was basically still underestimated and tended to be stronger. Market confidence in the policy measures taken by the Government, Bank Indonesia, OJK and LPS in handling COVID-19 and its impacts, both in terms of fiscal, monetary and credit, and the risk conditions in the global market are gradually improving (bi.go.id).

Based on the presentation of the above data related to the problems of economic growth in Indonesia during the COVID-19 pandemic which was experiencing a recession, the government through the monetary and fiscal authorities carried out various policies to increase economic growth. The policies carried out are in the form of maintaining the stability of the rupiah exchange rate. Therefore, researchers are interested in 
conducting research with the title "Analysis of the Effect of the Rupiah Exchange Rate on Economic Growth in Indonesia".

\section{THEORICAL FRAMEWORK}

\subsection{Economic Growth}

Keynes' economic growth considers that the total income in the economy in the short term is largely determined by the desire of households, companies and governments to spend their income. According to Mankiw [7] in an open economy, national income $(\mathrm{Y})$ is determined by expenditure from the household sector (C), investment is expenditure from the corporate sector (I), government expenditure is expenditure from the government sector $(\mathrm{G})$ and exports of domestic goods and services. (EX). So that these components can be shown in the identity:

$\mathrm{Y}=\mathrm{Cd}+\mathrm{Id}+\mathrm{Gd}+\mathrm{EX}$

The sum of the three $\mathrm{Cd}+\mathrm{Id}+\mathrm{Gd}$, is domestic expenditure on domestic goods and services, while EX is foreign expenditure on goods and services. Total expenditure on all goods and services is the sum of domestic spending on domestic goods and services as well as foreign goods and services, so that.

$\mathrm{C}=\mathrm{Cd}+\mathrm{Cf} \mathrm{I}=\mathrm{Id}+\mathrm{If}$

$\mathrm{G}=\mathrm{Gd}+\mathrm{Gf}$

Substitute equation (2.2) into equation (2.1) so that:

$\mathrm{Y}=(\mathrm{C}-\mathrm{Cf})+(\mathrm{I}-\mathrm{If})+(\mathrm{G}-\mathrm{Gf})+\mathrm{EX}$

$\mathrm{Y}=\mathrm{C}+\mathrm{I}+\mathrm{G}+\mathrm{EX}-(\mathrm{Cf}+\mathrm{If}+\mathrm{Gf})$

The amount of domestic expenditure on foreign goods and services ( $\mathrm{Cf}+\mathrm{If}+\mathrm{Gf}$ ) is expenditure for (IM), so the identity of the calculation of national income can be written:

$\mathrm{Y}=\mathrm{C}+\mathrm{I}+\mathrm{G}+(\mathrm{EX}-\mathrm{IM})$

Because spending on imports is included in domestic spending $(\mathrm{C}+\mathrm{I}+\mathrm{G})$, because goods and services imported from abroad are not part of a country's output, equation (2.4) must be deducted from spending on imports. By defining net exports as exports minus imports $(\mathrm{NX}=\mathrm{EX}-\mathrm{IM})$, the identity becomes:

$\mathrm{Y}=\mathrm{C}+\mathrm{I}+\mathrm{G}+\mathrm{NX}$
This equation states that spending on domestic output is the sum of consumption, investment, government spending and net exports.

\subsection{Rupiah Exchange Rate}

According to [9] exchange rate is the exchange of two different currencies, so you will get a value/price comparison between the two currencies. A decrease in an exchange rate is called an appreciation or increase or increase in the value of the domestic currency, an increase in an exchange rate is called depreciation or a decrease in the value of the domestic currency against foreign currencies.

\subsection{Mundell-Fleming Model}

A Mundell Fleming model that shows how total ncome $\mathrm{Y}$ and the exchange rate e react to political changes. Point A describes the balance in the forex market where the capital account does not change when the domestic interest rate $(r)$ is equal to the world interest rate $\left(\mathrm{r}^{*}\right)$. Curve A has a zero slope because of the assumption of high capital mobility where the flow of funds into and out of a country is due to differences in domestic and world interest rates.

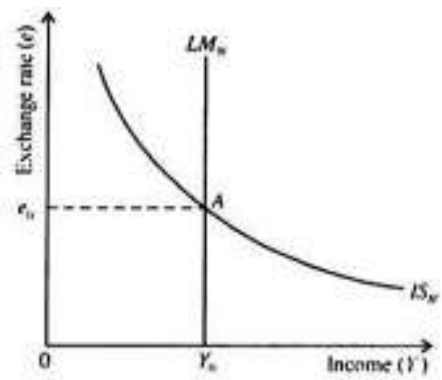

Figure 3 Mundell-Fleming model Source: Mankiw, Macroeconomics 2007

Figure 3 illustrates the Mundell-Fleming model with the existing level of output (income) and Rupiah exchange rate. The IS curve describes the equilibrium in the goods market where the level of output produced is equal to the level of output that people want to consume. The IS curve has a negative slope because an increase in interest rates will decrease national output. The LM curve describes the balance in the money market where the amount of money circulating by the central bank is equal to the amount of money that people want to hold. The LM curve has a positive slope because an increase in the Rupiah exchange rate will reduce the amount of money people want to hold, thereby reducing income.

\subsection{The Relationship of the Rupiah}




\section{Exchange Rate to Economic Growth}

Mundell-Fleming theory [7] states that there is a negative relationship between the exchange rate and economic growth, where the higher the exchange rate, the lower net exports (the difference between exports and imports), this decline will have an impact on the amount of output that is increasing. reduced and will cause GDP to decline. Utami [10] analyzed the effect of inflation, foreign exchange, BI Rate, money supply on economic growth. Idayanti [5] analyzed the effect of inflation, the exchange rate, the money supply, the SBI interest rate on post-crisis economic growth, all of which showed empirical evidence that the exchange rate had a negative effect on Indonesia's economic growth.

\subsection{Variable Dummy Concept}

In statistics and econometrics, especially in regression analysis, dummy variables are also known as indicator or qualitative variables as a way of taking values of zero (0) and one (1) indicating the absence or presence of some categorical effect that can be expected to shift the results. (Gujariat 2006).

In this study, the benchmark used for the dummy variable is Covid-19. Where before the recession due to the Covid-19 virus was denoted the number 0 and in the Covid-19 condition it was symbolized by the number 1 .

\subsection{Conceptual Framework}

Broadly speaking, the conceptual framework can be described in the following figure:

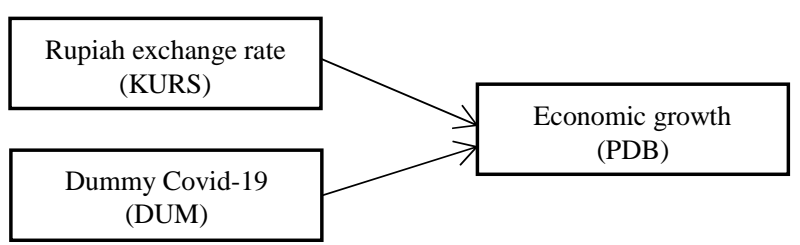

Figure 4 Conceptual Framework

\section{REASEARCH METHOD}

This study uses the Error Correction Model (ECM) analysis method. This is because this method allwos you to analyze short-term and longterm relationships between independent variables Rupiah exchange rate (KURS) on the dependent variable growth economy (PE). ECM test steps are data stationarity test, cointegration test, and ECM test.
The Error Correction Model (ECM) was popularized by Engle and Granger which is a testing tool used to correct and analyze the shortterm and long-term balance of each variable [3]. In addition, ECM can also be used to explain why economists face imbalances in terms of phenomena that economists expect do not match reality. The basic equations compiled in this study are as follows: $\beta 4$

$\mathrm{PDB}=\beta 0+\beta 1 \mathrm{KURS}+\beta 2 \mathrm{SUN}+\beta 3 \mathrm{SBSN}+$

$$
\mathrm{DUM}+\varepsilon \mathrm{i}
$$

Furthermore, the equation is formulated in the form of an error correction model (ECM), and the equation looks like this:

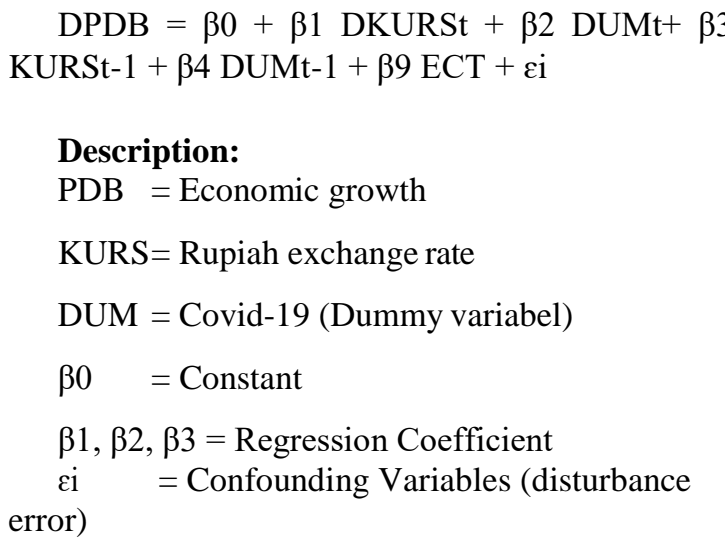

\section{ANALYSIS}

\subsection{Unit Root Test}

The unit root test or the stationary test of the data is carried out to test whether the data is stationary or not. The method that is widely used by econometricians to test stationary data problems is to use the unit root test or the unit root test with the Augmented Dickey Fuller Test (ADF) developed by Dickey Fuller. With the condition that the calculated ADF value is less than the critical value (Mackinon Critical Values) or the Probn is greater than the critical value $0.05(5 \%)$ then the data is not stationary and if the calculated ADF is greater than the critical value (Mackinon Critical Values) or the Prob value is less than or equal to the critical value $0.05(5 \%)$ then the data is stationary. The results of the unit root test can be seen in the following table: 
Table 1. Unit Root Test Results Using ADF Method

\begin{tabular}{|c|c|c|c|c|}
\hline Variable & $\begin{array}{c}\text { ADF T- } \\
\text { Statistics }\end{array}$ & $\begin{array}{c}\text { Critical } \\
\text { Value } \boldsymbol{a} \\
\mathbf{= 5 \%}\end{array}$ & Prob & Conclusion \\
\hline $\begin{array}{c}\text { Economic growth } \\
\text { (PDB) }\end{array}$ & $-1,169573$ & $-2,935001$ & 0,6784 & Nonstasioner \\
\hline $\begin{array}{c}\text { Rupiah exchange } \\
\text { rate (KURS) }\end{array}$ & $-1,857258$ & -2.936942 & 0,3484 & Nonstasioner \\
\hline
\end{tabular}

Source: Data processed with views 10

\subsection{Integrity Test}

Integrity The test is the test that was run to measure the level of differentiation of how many variables are stationary. The degree of integrity test also uses the Augmented Dickey Fuller Test (ADF) method at a critical value of $5 \%$. Data that is not stationary at the level level is retested until all data is stationary at the same level at the first and or second differentiation level of differentiation. The following are the results of the ADF test on the first difference:

Table 2 Results of Unit Root Test Using ADF Method on First Difference

\begin{tabular}{|c|l|l|l|l|}
\hline Variable & $\begin{array}{l}\text { ADF T- } \\
\text { Statistics }\end{array}$ & $\begin{array}{l}\text { Critical } \\
\text { Value } \boldsymbol{a} \\
\mathbf{= 5 \%}\end{array}$ & Prob & Conlusion \\
\hline $\begin{array}{c}\text { Economic } \\
\text { growth (PDB) }\end{array}$ & $-10,11063$ & $-3,610453$ & $-2,938987$ & $-2,607932$ \\
\hline $\begin{array}{c}\text { Rupiah } \\
\text { Exchange Rate } \\
\text { (KURS) }\end{array}$ & $-9,575922$ & -3.605593 & $-2,936942$ & -2.606857 \\
\hline
\end{tabular}

Source: Data processed with views 10

\subsection{Cointegration Test}

Cointegration test is a test carried out to determine whether there is a long-term balance in the model that has been formed. In this study, the cointegration test used the residual based test method. This residual based test method uses the augmented dickey fuller (ADF) statistical test, namely by observing the stationary cointegration regression residual or not.

\begin{tabular}{|c|c|c|c|}
\hline \multicolumn{4}{|c|}{$\begin{array}{l}\text { Null Hypothesis: ECT has a unit root } \\
\text { Exogenous: Constant } \\
\text { Lag Length: } 0 \text { (Automatic - based on } \mathrm{HQ}, \text { maxlag=1) }\end{array}$} \\
\hline & & t-Statistic & Prob.* \\
\hline Augmented Dickey- & uller teststatistic & -3.186159 & 0.0281 \\
\hline \multirow{2}{*}{ Test critical values: } & $1 \%$ level & -3.600987 & \\
\hline & $\begin{array}{l}5 \% \text { level } \\
10 \% \text { level }\end{array}$ & $\begin{array}{l}-2.935001 \\
-2.605836\end{array}$ & \\
\hline
\end{tabular}

Source: Data processed with views 10

Table 4.7 above shows the ADF test value ($3.186159)>$ critical value $(-2.935001)$ and with an ECT probability value of $0.0281<0.05$. The ECT value is stationary at the level level, it means that the residual from the equation is stationary at the zero integrity degree (0) or the level level. Therefore, there is a significant relationship (cointegration) in the long term between the independent variable and the dependent variable. From these results there is cointegration and this research can be continued with the ECM test.

Table 4. Estimation Results with the ECM Method

\begin{tabular}{|c|c|c|c|c|}
\hline Variable & Coetticient & 5td Emor & t-5tatistio & Prob \\
\hline $\begin{array}{c}\text { DOKUIR:5) } \\
\text { D(DUM } \\
\text { EOT } \\
\text { KURS(-1) } \\
\text { DUM(-1) } \\
\text { C }\end{array}$ & $\begin{array}{l}2.119601 \\
0.070182 \\
0.168817 \\
8.096079 \\
0.002172 \\
0.012680\end{array}$ & $\begin{array}{l}0.96 E-06 \\
0.028000 \\
0.076809 \\
2.04 \mathrm{E}-00 \\
0.012451 \\
0.025476\end{array}$ & $\begin{array}{l}3.046527 \\
2.378017 \\
2.065001 \\
0.320278 \\
0.174416 \\
0.772815\end{array}$ & $\begin{array}{l}0.0044 \\
0.0228 \\
0.0404 \\
0.0943 \\
0.8620 \\
0.4448\end{array}$ \\
\hline 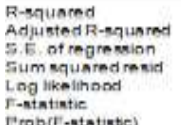 & $\begin{array}{l}0.315231 \\
0217475 \\
0.023341 \\
0.013083 \\
33.12502 \\
3.223319 \\
0.010945\end{array}$ & $\begin{array}{l}\text { Menn def } \\
\text { SD depe } \\
\text { Akgike int } \\
\text { Schwnrz } \\
\text { Hannmn-C } \\
\text { Durbin-W }\end{array}$ & 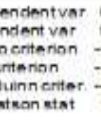 & $\begin{array}{r}0.011747 \\
0.026380 \\
-4542727 \\
-4.231956 \\
-4.451407 \\
1.964972\end{array}$ \\
\hline
\end{tabular}

Source: Data processed with views 10

Based on the estimation results using the Error Correction Model (ECM) method, the ECT (Error Correction Term) value is obtained with a positive and significant $\operatorname{sign}$ at $\mathrm{a}=5 \%$ for the estimated economic growth (GDP). The short-term Error Correction Model (ECM) is as follows:

$\mathrm{D}($ LOGPDB $)=0,019690+2.119601 \mathrm{D}(\mathrm{KURS})-$ $0,070182 \mathrm{D}(\mathrm{DUM})+\varepsilon \mathrm{i}$

The results of the ECM estimation above show that short-term changes in the rupiah exchange rate (KURS) variable have a positive impact on Indonesia's economic growth (GDP). Meanwhile, the Covid-19 dummy (DUM) has a negative impact on economic growth (GDP), ceteris paribus. The error correction model (ECM) in the long term is as follows:

$($ LOGPDB $)=0,019690-8,095679$ KURS $(-1)+$ $0,002172 \operatorname{DUM}(-1)+\varepsilon \mathrm{i}$

The results of the ECM estimation above show that long-term changes in the rupiah exchange rate (KURS) variable Has a negative impact, and the Covid19 dummy (DUM) has a positive impact on Indonesia's economic growth (GDP).

\section{4. t-Statistics Test}

This test is conducted to determine whether partially each independent variable has a significant 
effect or not on the dependent variable.

a) The rupiah exchange rate (KURS) variable has a t- statistic value of 3.046527 , the results of data processing The rupiah exchange rate (KURS) has a positive coefficient of 2.119601 with a prob value of $0.0044<0.05$. $\mathrm{T}$ his means that the rupiah's exchange rate will have a significant impact on Indonesia's economic growth (GDP) in the short term.

b) The Covid-19 dummy variable (DUM) has a tstatistic value of -2.379047 , the results of processing the Covid-19 dummy data (DUM) have a negative coefficient of -0.070182 with a prob value of $0.0299<0.05$. This means that in the short term the Covid-19 dummy (DUM) has a significant effect on economic growth (GDP) in Indonesia.

c) The rupiah exchange rate (KURS) variable has a t- statistic value of 0.396278 , the result of data processing The rupiah exchange rate (KURS) has a negative coefficient of -8.095679 with a prob of $0.6943>0.05$. This means that the rupiah's exchange rate does not have a significant longterm impact on Indonesia's economic growth (GDP).

d) The Covid-19 dummy variable (DUM) has a tstatistic value of 0.174416 , the result of processing the Covid-19 dummy data (DUM) has a positive coefficient of 0.019690 with a prob of $0.8625>0.05$. This means that the Covid19 dummy (DUM) will not have a significant longterm impact on Indonesia's economic growth (GDP).

\subsection{F-Statistics Test}

Based on the results of data processing using the short-term and long-term Error Correction Model method, the F-statistic value is 3.223319 with a probability of 0.016946 which is smaller than $\mathrm{a}=$ $5 \%(0.05)$. From this, we can conclude that the variable rupiah exchange rate (KURS) and the Covid19 dummy (DUM) have a significant impact on Indonesia's economic growth (GDP) at the same time in the short and long term.

\subsection{Coefficient of Determination Test $\left(\mathbf{R}^{\mathbf{2}}\right)$}

Based on the results of data processing with the short-term and long-term Error Correction Model method, the R-squared value is 0.315291 or $31.51 \%$. From this, the exchange rate of the rupiah is (KURS) and Covid19 dummy (DUM) variables contributed to economic growth (GDP) in Indonesia by $31.51 \%$ while the remaining $68.49 \%$ was influenced by other variables outside this research model.

\section{RESULTS AND DISCUSSION}

\subsection{The Effect of the Rupiah Exchange Rate on Economic Growth in Indonesia}

The results showed the fact that the rupiah exchange rate has a positive and significant positive impact on economic growth in the short term and is not important in the long term means that the rupiah exchange rate has a negative impact on both shortterm and economic growth. It does not correspond to the hypothesis long-term. The results of this study are evidenced by the depreciation of the rupiah exchange rate in the 1st quarter of 2020 of IDR 16,310 yoy followed by economic growth which also increased by $2.97 \%$ yoy and also the depression of the rupiah exchange rate in the 2 nd quarter of 2021 of IDR 14,500 yoy followed by growth economy which also increased by $7.07 \%$ yoy. The weakening of the rupiah exchange rate was the result of the public's demand for foreign currency to conduct transactions in international trade.

The results of this study in the long term are in accordance with the research of [6] who conducted research on "Exchange rate systems and economic growth in Central and Eastern European countries". Authorities supporting the rupiah exchange rate. The results also show that fluctuations appear to stimulate growth, but most countries adhere to fixed exchange rates. The monetary system is a view that may not last long, but it is only suitable for the short term.

\subsection{The Effect of the Covid-19 Dummy on Economic Growth in Indonesia}

The Covid-19 dummy variable (DUM) based on research results has a significant negative impact on economic growth in the short term (GDP) in Indonesia. This means that if there is an increase in the Covid-19 dummy variable (DUM), It will reduce Indonesia's economic growth (GDP). This is indicated because the Covid-19 outbreak that spreads in Indonesia can paralyze the economy in the short term so that Indonesia's economic growth slows down or does not grow or is negative. Where many people are affected by the disease due 
to Covid-19 so that there is a lockdown to reduce its spread. Due to Covid-19, many companies have also reduced their workforce due to reduced sales turnover, resulting in massive unemployment.

Meanwhile, in the long term the Covid-19 dummy variable (DUM) has no a great impact on Indonesia's economic growth (GDP). This means that if there is an increase in the Covid-19 dummy variable (DUM), it will increase economic growth (GDP) in Indonesia. This is indicated due to the prolonged Covid- 19 outbreak, the Indonesian government has anticipated its spread by implementing a lockdown, work from home (WFH), and the imposition of restrictions on community activities (PPKM) to reduce the spread of the Covid-19 virus. In addition, the government has also made various monetary and fiscal policies to increase Indonesia's economic growth during the Covid-19 pandemic. Therefore, the Indonesian government has taken various steps to reduce the spread of Covid 19 and enable the Indonesian economy to grow in the long term.

\section{CONCLUSIONS}

Extra efforts to stabilize the rupiah exchange rate against the dollar need to be carried out by the government and the Indonesian bank so that the strengthening of the Indonesian currency can reduce domestic prices in order to encourage and improve Indonesia's export performance. With the increase in Indonesian exports, economic growth can be achieved in the long run by strengthening the rupiah rate against the dollar, but in the short term by weakening the rupiah rate can increase Indonesia's economic growth. This is not good when the rupiah exchange rate experiences a prolonged depression.

To maintain Indonesia's economic growth conditions during the Covid-19 pandemic, the government and Bank Indonesia are more careful in making policies. The paralysis of the national economy caused by the Covid-19 pandemic did not only have an impact on the domestic economy, it even had an impact on relations with the international economy. In addition, the government can encourage national economic recovery with various efforts that do not pose a prolonged risk to the economy in the future.

Further researchers who wish to conduct similar research, can add other variables and improve the steps of this method or with other methods such as VAR, 2SLS.

\section{REFERENCES}

[1] Bank Indonesia. Kajian Ekonomi dan Keuangan Regional. Laporan Nusantara, 2020, pp 104.

[2] Corbet, S., Hou, Y. (Greg), Hu, Y., Oxley, L., $\& \mathrm{Xu}, \mathrm{D}$., Pandemic-relatedi financial marketi volatilityi spillovers: Evidence from the Chinesei COVID-19 epicentre. International Review ofi Economics and Finance, 71 (September 2020), 2021, pp 55-81. https://doi.org/10.1016/j.iref.2020.06.022i

[3] Ghozali, I., Aplikasi Multivariat DAN Ekonometrika dengan Eviews 10. Semarang. BPUNDIP. 2018.

[4] Gujariat. Ekonometrika Dasar. Jakarta. Erlangga. 2006

[5] Idayanti, E. Pengaruhi Kebijakan Moneteri Terhadapi Pertumbuhan Ekonomi Pasca Krisisi Di Indonesia (Januari 1999 iDesember 2003). 2005, pp 1-145.

[6] Ihnatov, I., \& Căpraru, B., Exchange Rate Regimesi and Economic Growth ini Central and Eastern European Countries. Procedia Economics and Finance, 3(12), 2012, pp 1823. https://doi.org/10.1016/s22125671(12)00115-3

[7] Mankiw, N.Gregory., Makroekonom, Edisi Keenam. Jakarta. Erlangga. 2007.

[8] Messaoud, B., \& Teheni, Z. E. G. , Business regulationsi and economic growth: What ican bei explained? International Strategic Managementi Review, 2(2), 2014, pp 69-78. https://doi.org/10.1016/j.ism.2014.03.001

[9] Nopirin. Ekonomi Moneter, Edisi Satu. Yogyakarta. BPFE UGM. 2009

[10] Utami, R. F., Terhadap Pertumbuhan Ekonomi Di Indonesia Periode 2002-2012. Jurnal Ekonomi \& Kebijakan Publik, 12(05), 2013. Pp 1-5. 